\title{
Automatic Stabilizing Mechanisms Under FreE BanKing Kevin Dowd
}

\section{Introduction}

One objective of this paper is to explain the automatic stabilizing mechanisms inherent in a free banking system. Starting from an initial primitive state of society, I will suggest how a banking system would evolve in the absence of state intervention. The state is assumed only to enforce contracts freely entered into by private individuals. Government expenses are paid through taxation, but there is no taxation specific to the monetary system. (In other words, there is no seignorage.) The evolutionary process is driven by individuals' pursuit of their own private interests, and no one consciously attempts to promote any wider "social interest." At each stage individuals seek to reduce their exchange or operating costs, and these attempts lead to the growth of new institutions that reduce the costs of coordinating economic activity. ${ }^{1}$ With no state interference to hinder it, this evolutionary process would lead to the development of a highly sophisticated "free banking system" with several distinctive features, including: (1) multiple note issuers who would guarantee to redeem their notes in a commodity that the community recognizes as valuable; (2) a regular note exchange between these note issuers; and $(3)$ the insertion of "option clauses" into the convertibility con-

Cato Journal, Vol. 7, No. 3 (Winter 1988). Copyright (C) Cato Institute. All rights reserved.

The author is Lecturer in Economics at the School of Management and Economic Studies, University of Sheffield, Sheffield, England. He would like to thank Charles Goodhart, Catherine England, Jack Gilbert, Richard Timberlake, Lawrence H. White, and several anonymous referees for helpful comments.

'This "invisible hand" method of explaining institutional growth was pioneered by the Scottish moral philosophers of the 18 th century and has been widely used by social scientists ever since. Menger (1892) used it to explain the development of money, for instance, and it has been used by a number of other writers to explain the evolution of the banking system. See, for example, Wesslau (1887), Meulen (1934), and Selgin and White (1987), among many others. My discussion relies heavily on these earlier studies. 
tracts to protect the note issuers against sudden excessive demands for liquidity, Each of these would contribute significantly to the stability of the monetary system, making the resulting monetary equilibrium a highly stable one.

The second objective of this article is to compare the stability of the free banking system with that of the highly regulated, central banking monetary regimes we have today. Showing how the monetary system would have evolved in the absence of state interference provides a benchmark against which to assess the effects of that interference. The essential difference between free banking and centra] banking is that the latter involves the suppression of stabilizing mechanisms that would arise spontaneously without government interference. This strongly suggests that central banking is a destabilizing form of state intervention.

\section{The Evolution of a Free Banking System}

\section{The Development of Coins}

In a relatively primitive society in which individuals are just beginning to trade with each other, "coincidence of wants" problems would arise frequently if market participants are restricted to barter exchanges. Some goods would be more in demand than others, however, and at some stage individuals would realize that they have a better chance of getting the goods they want if they first accept some popular intermediate good and then swap it for the good they want to consume. This resort to "indirect exchange," which employs a certain class (or classes) of intermediate goods, would allow individuals to avoid the "coincidence of wants" problem, but their transactions costs would remain high. In particular, they would still need to measure the quantity of the goods they were offered and assess their quality. They would therefore prefer intermediate goods whose quantity was easily measured and whose quality was relatively uniform. 'To minimize transportation and storage costs, market participants would also want goods that were sufficiently scarce that small amounts would have a high exchange value. Historically, people have tended to converge on the precious metals as desirable intermediate goods and to abandon alternatives as the advantages of precious metals became more apparent.

The use of precious metals as intermediate goods would still leave individuals with the inconvenience of weighing lumps of metal and assessing their purity. This would create an opportunity for some individuals to act as intermediaries and make their living assessing the purity of the metal brought to them and recasting it into pieces 
of more convenient size. As such practices spread, the fineness and sizes of metal pieces would gradually become standardized, and the private intermediaries would mark the pieces to show their weight and quality. The profits made by the earliest of these intermediaries would attract others, and they would compete with each other for business. It would not take long to realize that they could attract more business by using distinctive marks on the metal pieces they issued. The intermediaries would thus become private mints and their metal pieces privately issued coins.

Each of these private mints would exist primarily to maximize its own profits, which could be generated in several ways. One is by offering competitive minting fees. Another is by developing a reputation for probity to reassure prospective customers that they would not be cheated. A third is by innovation: mints would experiment with coins of new denominations, alternative metals, and so on. Any successful innovations would be imitated by other mints and would become widely adopted. It bears stressing that these mints would have no incentive to cheat by overstating the weight of their coins because such deception would be easy to detect, and this would damage the mint's reputation and hence its business. Furthermore, the law would classify such activity as fraud. ${ }^{2}$

As an aside, it is exactly at this stage that the state historically has intervencd in the monetary system. Governments realized they could use their coercive powers to create a legal monopoly that would make the minting business very profitable. Even if the government's service was inferior to that of private mints, the public could be forced to accept it as the state would prohibit its subjects from using the coins of other mints. 'The government could then impose high minting charges or misrepresent the weights of the coins it issued. Note that it is only the state's monopoly over the means of legal coercion that enables the state mint to stay in business. A private mint could not provide an inferior service and survive because it would have no way of compelling people to use its services.

\footnotetext{
${ }^{2}$ It could be argued in this case that the law of fratud would be redundant. It would be in the interests of a mint to pay people of unquestioned probity to issue regular reports on the quality of its coins. This would allow the mint to maintain a reputation for honesty and thereby promote its business. All dishonest mints would be thus exposed and driven ont of business. This is yet nnother example of the ability of the unrestrained private sector to police itself quite effectively.

${ }^{3}$ Monetary history is unfortunately full of instances of this abuse of the monetary system. For example, see the Cambridge Economic History of Europe, vol. 5, chap. 5, "Money, Credit and Banking Systems."
} 


\section{Cato Journal}

\section{The Development of Banks Issuing Convertible Notes}

The use of coins would still involve considerable costs, particularly the costs of storage (including the costs of ensuring that one's coins were safe), and the costs of moving coins around. To avoid storage costs, some people would be prepared to pay others who already had the facilities to keep gold safe-those with strongboxes-to store their gold for them. In practice, this would mean metalsmiths ("goldsmiths") or merchants who regularly kept large amounts of gold or silver would be asked to look after other people's gold for a fee, and they would probably do so because the marginal cost would be quite low. Depositors would obtain receipts from those holding their gold or silver attesting to the value of each deposit made.

As the practice spread, it would increasingly happen that when two people agreed on an exchange, one would go and withdraw his coins and hand them over to the other who would deposit them again. Provided that the party accepting payment was satisfied that the goldsmith was likely to honor his commitment, it would be more convenient for him simply to accept the goldsmith's receipt and save both parties the bother of visiting their goldsmiths. Goldsmiths' receipts would thus begin to circulate as media of exchange in their own right. At the same time, the goldsmiths would begin to notice that only a small proportion of their deposits of gold would be demanded in redemption over any given period, and they would realize that they could lend out some of the gold deposited with them and face little danger of being unable to meet their liabilities. This lending activity would give them an opportunity to carn an additional profit.

The goldsmiths would thus become bankers and begin to compete with each other for deposits. One way to do this would be to offer interest on deposits, replacing the earlier fees charged depositors for the safekeeping of their money. More importantly, the goldsmithbankers would also compete for deposits by offering guarantees to prospective depositors that the receipts-notes issued by them would retain their value. Perhaps the most persuasive guarantee they could offer would be to make their notes "convertible," that is, to promise to convert their notes back into specie. The goldsmith-bankers would in fact have offered such promises right from the start, of course, because no one would have made deposits with them unless they were assured that they could withdraw them. These guarantees would have the status of legally binding contracts, and the violation of such a contract would therefore expose the banker to the legal penalty for default, which we will assume is sufficiently high to make a banker careful to avoid it. 
This commitment to convertibility is one of the most important features of a free banking system, and it has several major implications. First, it would help ensure that bank notes remained relatively stable in value. The value of convertible notes would be tied to the value of gold. It follows that the exchange value of notes against goods in general would fluctuate only with changes in the relative price of gold-that is, the exchange rate between gold and other goods-and we would not normally expect this to be particularly volatile. We might therefore expect the price level to be reasonably stable.

Second, the commitment to convertibility would provide an effective discipline against goldsmith-bankers who issued an excess of notes. When banks issued convertible notes, their circulation would be limited by the demand to hold them. That demand would depend on such factors as the precise features of the convertibility contract (for example, whether the depositor has to give notice when he wants to withdraw his deposit), the bank's reputation, the familiarity of its notes, the number of branches it maintains, and so on. Any notes issued beyond the demand to hold them would be returned for redemption. A bank would not deliberately choose to issue an excess of notes because they would not remain in circulation long enough to justify the expense of putting them into circulation and then taking them back again. If a bank sought to increase its note issue, it might attempt to improve its reputation, advertise its notes more, or open more branches. But it could not increase its note issue simply by putting more notes into circulation. It is one thing to put more notes into circulation, but it is quite another thing to keep them there.

\section{The Development of Note-Clearing}

The next stage in the evolution of the banking system would be the development of a note-clearing system that would arise out of bankers' attempts to raise their profits by increasing the demands for their notes. In the beginning, no banker would accept the notes of other banks when submitted by the public because to do so would make rivals' notes more acceptable and raise its competitors' profits. But any two banks could make themselves jointly better off by agreeing to accept each other's notes. Each bank would benefit because the public would more readily accept the notes of either of the two banks given the knowledge that the other bank would accept the notes at par as well. The notes of these two banks would thus become marginally more attractive than alternative media of exchange such as gold or the notes of other banks. Thus, additional bank pairs would be formed, and it would become increasingly apparent that the eas- 


\section{Cato Journal}

iest way to organize the note exchange system would be to meet regularly at a central clearing session where the banks would hand back each others' notes and settle the differences." In this way a central clearing system would evolve out of the banks' own private self-interests. ${ }^{5}$

The clearing system is important because it would provide a further restraint on the ability of any one bank to overissue its notes. Without the clearing system a bank that overissued would face a reserve drain only from the general public's returning its notes for specie, and it could take some time for this to force the bank to restrain its issues. Once the clearing system was in place, however, a bank issuing more notes than the public wanted would also face reserve losses at the central clearing sessions. These losses would occur as the public deposited the extra notes at other banks and those banks returned them to the issuing bank. A bank that overissued notes would thus lose reserves through two channels-through direct redemption by the public, and through indirect redemption via the clearing system-but the latter channel would likely operate more quickly.

\section{The Development of a Liquidity Market}

We have seen the bankers' self-interests would lead to note convertibility and to a central clearing system, and both of these would discipline any bank that overissued its notes. They would therefore contribute significantly to the stability of the monetary system. However, if a bank was committed to redeem all its note liabilities on demand, it would still face a problem of potential illiquidity given its ability to redeem only a fraction of its liabilities at any given time. With sufficient advance notice, a sound bank would be able to meet demands for redemption by liquidating assets, ${ }^{6}$ but a problem could arise if it failod to receive the notice it needed. It is this lack of notice that gives rise to the possibility that an otherwise sound bank might become illiquid and unable to honor its obligations.

Two institutions would develop to deal with this problem. The first would be the growth of a market in short-term liquidity. This

"It would not take the banks long to realize that it was expensive to use gold as the medium in which to settle clearing balances. They would therefore introduce a paper clearinghouse medium and use that instead. An historical instance of this is the development of clearinghouse loan certificate among the members of the New York Clearing House Association in the late 19th century. An excellent discussion of this is given in Timberlake (1984).

${ }^{5}$ The evolution of the clearing system is explained in White (1984) and Selgin and White (1987).

GIt the bank is unsound then it should go out of business anyway. The liquidity problem we discuss is only a source of concern when it affects sound banks. 
would arise because bankers' holdings of liquidity would be subject to random short-term fluctuations that are difficult to predict accurately. At any given time some banks would find themselves with more liquidity than they had anticipated and others with less. Those with "excess" reserves would be willing to lend them out on a shortterm basis, while those that were short of reserves would be willing to borrow them, making both groups better off. Experience would teach the lending banks what kind of collateral policy to adopt, what information they needed from prospective borrowers, and so on.

\section{The Development of Option Clauses}

However a bank could borrow only if others were ready to lend to it. This is an important qualification because it means that the banking system as a whole might not be able to obtain the reserves needed from the liquidity market, even though any individual bank could. ${ }^{7}$ This constraint could pose a problem if an unexpectedly high demand for cash caused the short-term liquidity market to dry up temporarily as everyone demanded more reserves and no one was willing to supply them. ${ }^{8}$ In principle, this could cause the banking system to collapse. Since this danger is caused by the banks' commitment to redeem their notes on demand without notice, the banks might try to avoid it by modifying the convertibility contract on their notes. Instead of guaranteeing to redeem their notes for specie on demand, the banks could reserve the right to defer redemption for some prespecified period on the condition that noteholders would be paid a prespecified compensation when the notes were finally redeemed. In other words, the bankers could insert clauses into the convertibility contract that would give them the option of deferring redemption.

These "option clauses" would need to be carefully designed. ${ }^{9}$ To remain in business, a bank that introduced option clauses would

\footnotetext{
${ }^{7}$ There is another possible source of liquidity that we have neglected. If the economy is an open one, then gold can always be obtained from abroad. If gold can be imported reasonably cheaply and quickly, then the chances of the banking system being rendered illiquid are reduced, probably very significantly. I have chosen to ignore this possibility in order to stress the extent to which the domestic economy could evolve ways of helping itself. Alternatively, one could consider the economy I analyze to be the world economy that does not have the option of importing gold.

${ }^{8}$ Frankly, I see no particular reason why such a situation should arise under laissezfaire, as distinet from central banking, but it appears to be a major concern in the literature. See, for example, Gorton (1985) and Goodhart (1985). I discuss it simply to show how a laissez-faire banking system could handle it.

Economists have paid very little attention to the potential of option clauses to deal with problems of illiquidity. The pioneer in the field is Henry Meulen (1934) whose treatment of the problem has been unduly neglected.
} 


\section{Cato Journal}

need to reassure the public that its notes were still safe. It would want to make a credible promise that it would only use the option in exceptional circumstances and that noteholders would suffer no losses even then. To be convincing the bank would need to set the compensation paid to noteholders at a level sufficiently high so that it would never be in the bank's interest to exercise the option except in an emergency. The bank might also stress the advantages of the option clause to the risk-averse noteholder. ${ }^{10}$ Those noteholders slow to react to a run on specie would lose little or nothing by their failure to be first in line, and indeed would gain from the compensation the bank would have to pay for suspending convertibility. And even if the bank should turn out to be insolvent as well as illiquid, then losses would be shared on a pro rata basis among noteholders and other bank creditors rather than falling disproportionately on those who were not quick enough to demand redemption before the bank suspended. It would thus be clear to the public that the bank would only resort to the option as a last resort, and that the option, if anything, would probably make individuals better off.

Trial and error in the marketplace would determine the period over which redemption could be deferred and the interest to be paid on notes whose redemption was suspended. The exact form of the option clause is therefore difficult to predict beforehand. The compensatory interest rate would presumably be linked to the interest rate in the short-term liquidity market. A plausible formula would be " $x$ points above the average rate prevailing in the short-term market over the past $y$ months." With such a formula, the option would never be exercised in "normal" times because a bank could always obtain liquidity more cheaply on the short-term market. If a liquidity crisis were to develop, however, the short-term interest rate would rise very sharply, and once it rose beyond a certain threshold level, it would be cheaper for the bank to obtain-or strictly speaking, retain-liquidity by invoking its option to defer payment. For simplicity we assume that all banks face the same threshold level, ${ }^{11}$ leading all banks to invoke their options simultaneously.

This would set in motion a chain of events that would break the crisis, send interest rates downward again, and alleviate the shortage of liquidity. In the period immediately after the banks started to exercise their options, market interest rates would remain above the penalty rates the banks were paying through the use of their options,

\footnotetext{
${ }^{10}$ I should like to thank one of the referees for suggesting these advantages to me.

${ }^{1}$ One would expect that competition would leave the banks facing similar thresholds. The analysis can easily be modified to allow for threshold differences.
} 
making it worthwhile for banks to borrow by invoking their options and to lend on the short-term liquidity market. The banks would thereby channel liquidity to where the demand for it was greatest, thus beginning to alleviate the shortage of liquidity and causing market interest rates to begin to fall. The banks would continue these arbitrage activities until the market interest rate had come down to the penalty level. Once it reached this level, the banks would no longer derive any benefit from exercising their option to defer redemption, and they would be ready to resume redemption on demand. By the time interest rates had fallen to this level, the public's panic for liquidity would have abated. As the demand for liquidity continued to fall, interest rates would return to pre-panic levels. ${ }^{12}$ The introduction of option clauses would thus protect the liquidity of the banking system and break the panic. The knowledge of this would itself make the banking system considerably more stable by eliminating the possibility of a bank run starting because of the public's self-fulfilling expectations of a run..$^{13}$

This completes our discussion of the evolution of a laissez-faire banking system. Note, in particular, how institutions like convertibility, a clearing system, a market for short-term liquidity, and option clauses would develop and protect the banking system against shocks. The sole driving force behind these stabilizing mechanisms would be individuals' self-interested attempts to protect themselves against adverse conditions. A free market monetary system would thus be highly stable.

\section{The Effects of State Intervention into the Monetary System}

We have seen how an ideal monetary system would have evolved had only two conditions been satisfied: (1) that individuals promote their own private interests, and (2) that the state adopt a policy of benign neglect and do nothing except enforce contracts freely made by private agents. Of these two conditions, the first appears to occur regularly while the second is much more difficult to achieve. A casual glance at monetary history will confirm that states have interfered in the monetary system on an almost continuous basis. Recent monetary

\footnotetext{
${ }^{12}$ I have assumed that the increased demand for liquidity is only temporary and that the panic subsides once it has peaked. This appears to be a fair characterization of historical liquidity crises.

${ }^{13}$ Self-fulfilling expectations of bank runs have been a major source of concern in the literature. See Gorton (1986). It is therefore reassuring to know that they do not arise under free banking.
} 


\section{Cato journaL}

history also confirms that the current monetary system is frequently unstable and very different from the system that would have evolved in the absence of state interference.

But why did a less stable monetary system come to replace a more stable one? The process begins when the state intervenes in the monetary system to raise revenue by suppressing competition and forcing its subjects to accept a quality of service they would reject if they had a wider freedom of choice. At first this intervention takes the form of establishing a government-sponsored bank with a monopoly over note issues. Regulations are also imposed on other banks. These interventions prevent a clearing system from developing and make the private sector banks more vulnerable to shocks, thus undermining the stability of the banking system. The state also frequently turns to the private banking system for forced loans when there is a fiscal crisis (such as a war), and this pressure further weakens and destabilizes it. By this stage public concern about the instability of the banking system has become acute, and the state feels obliged to intervene further to try to stabilize the monetary system. Banks' activities are then regulated and supervised to improve their "safety and soundness." This intervention increases the instability even more, and we end up with the monetary system we have today.

\section{The Effects of a Monopoly Note Issue}

Establishing a monopoly bank of issue serves to destabilize the monetary system in several ways. The absence of competition and alternative currency choices makes it more difficult for the public to get rid of an overissue of notes, creating more economic disruption in the presence of a currency monopoly than with multiple competing note issuers.

With multiple banks of issue a bank that overissues its notes would be checked relatively quickly by clearing losses. If there is only one bank of issue, however, there cannot be a clearing system, so the only check on overissue would be direct redemption of the notes by the general public, and this would take somewhat longer. (Assuming, that is, that it is allowed to occur in the first place. With an inconvertible currency, as we have at present, there is no automatic check at all against overissue.) Another way of looking at the difference is to see a monopoly bank's overissue as similar to what would happen if multiple banks of issue were able to form a cartel and expand in tandem, so that none suffered clearing losses. The banks would still be disciplined when the public brought in notes for redemption, but 
the process of correcting the overissue would obviously take longer. A larger overissue could take place than would have occurred otherwise, and the economic disruption it would cause would obviously be greater.

The lack of competitors thus gives a monopoly bank of issue greater discretion than any competitive bank would have. But it then has to face the problem of how to use that discretion. The governmentsponsored monopoly bank would have extreme difficulty judging the likely effects of its actions, and it would frequently have to fall back on its judgment and manage as best it could. To avoid this and make its actions consistent, the monopoly bank would try to develop rules of thumb to guide it on a day-to-day basis, but what should such rules be? In practice there is a wide range of possible policies to choose from, and it would be very difficult to choose one. ${ }^{14}$

This problem of finding the right policy would soon become even more difficult because the private banking system would adapt to the monopoly note issuer and gradually force the monopoly bank into the role of "guardian" of the monetary system. This would occur as private banks increasingly used the monopoly bank's notes as reserves. Paper would replace gold as the other banks' reserve medium because paper is easier to store and less costly to transport than gold, and becatse the public would generally prefer to withdraw their deposits in notes rather than gold. As notes replaced gold in circulation and in banks' vaults, the country's gold reserves would tend to become centralized in the vaults of the monopoly bank of issue. This would force on it the role of lender of last resort in a liquidity crisis. Even if it wanted to, the bank would find it difficult to ignore requests for assistance in a crisis because of the danger that the crisis would spread further and destroy it as well. Whether intended or not, the monopoly bank of issue would become responsible for protecting the nation's liquidity, and this would force it to take an increasingly broad view of the effects of its policies. The pressure to find the right policy would increase, but the right policy would be increasingly difficult to find.

\section{The Effects of Restrictions on Bank Organization}

A second source of instability is the regulation of the monetary system. In the early days of state intervention, regulations would be

\footnotetext{
14In general, there is no clear criterion that would allow policymakers to select one particular sule over another. If one adopts a monetary target, for instance, should it target $\mathrm{M} 1$, M2, or something else? If $\mathrm{Ml}$ is chosen, what version of $\mathrm{M} 1$ should be preferred? What should the target growth rate be? And so on. For any answer one gives to these questions, there is always another that is equally plausible, and one has no way of knowing which is best.
} 


\section{Cato Journal.}

imposed to reinforce the monopoly of the note issuer. A good example was the "six partner rule" embodied in an Act of the British Parliament of 1709. This Act restricted all banks in England and Wales to partnerships of no more than six persons. The intention was to reinforce the Bank of England's privileges (in return for which the Bank gave the government a subsidized loan). The Act effectively prohibited reliable (that is, large) aggregations of capital in banking as those partnerships that were allowed to enter the industry were too small to be able to withstand any substantial shock. People knew how vulnerable the banks were, and whenever there was any disturbance, they rushed to withdraw their gold. As a result, scores and sometimes hundreds of these banks failed. The "six partner rule" thus made English banking extremely unstable. Restrictions on branch banking have had a somewhat similar effect in the United States. Many examples of this kind of regulation exist. What they all have in common is that they destabilize the banking system by hindering the attempts of banks to protect themselves against shocks.

\section{The Effects of Further Government Demands for Reventue}

It soon become apparent that the state could not always obtain the revenue it wanted by simply establishing or strengthening a currency monopoly. Each time a war broke out the state would experience considerable-and often extreme-financial difficulties. Government expenditures would rise steeply, but it would be difficult (or at least awkward) to cover these additional expenditures by taxation or borrowing. The government would therefore pressure the banking system for subsidized loans instead. These loans would drain the banks' reserves and thereby expose the banking system to a liquidity crisis. This in turn would weaken the ability of the banking system to maintain convertibility and threaten not only the stability of the banking system, but also the stability of the value of the paper currency. The threat posed by these loans obviously depended on their size, but in some cases they led to the suspension of convertibility. In more extreme cases they also led to inflation.

Two historical examples will illustrate the point. In 1793 the government of William Pitt suddenly found itself at war with France. It had made no provision for war and was reluctant to raise taxes or to borrow enough to cover its additional expenditures. As its expenditures mounted, the government repeatedly applied to the Bank of England for loans. The Bank protested, but dared not refuse, and in making the loans its reserves were seriously depleted. The threat of French invasion in 1797 was then enough to trigger a major liquidity crisis that the Bank did not have the reserves to meet. It was only 
saved from insolvency by the government stepping in to abolish its commitment to redeem its notes. ${ }^{15}$ Convertibility was thus wrecked, in large part by the demands the government made on the Bank of England.

Something similar happened at the outbreak of the U.S. Civil War in 1861. When war broke out, the federal government found it difficult to obtain the revenue it wanted by borrowing from the general public. The Secretary of the Treasury therefore drew up a plan to borrow from the banks by compulsion. At the same time, he started to issue U.S. notes that he obliged the banks to redeem in specie. 'This put the banks' reserves under a great deal of pressure, and they were forced to suspend convertibility by the end of 1861 . The federal government then resorted to a series of issues of inconvertible paper money that produced a substantial inflation. ${ }^{16}$

In both these cases the pressure placed on the banking system was enough to destroy monvertibility. In each case, however, public opinion was sufficiently in favor of the principle of convertibility that convertibility was restored once peace had returned. The public was prepared to accept inconvertible paper currencies in an emergency like a war, but they were not prepared to accept them on a permanent basis. This antipathy to inconvertible currencies lasted throughout the 19th century and was reinforced by experiences in France during the assignat period, in England during the Restriction period (17971821), and in the United States during the Civil War suspension period (1861-1879).

This support for convertible currencies lasted until the 1920 s. Support for convertibility then fell as economies tried to readjust after the shock of the First World War and people became increasingly attracted by the idea that further state intervention in the economy was the only way to solve the major economic problems of the day. ${ }^{17}$ Supporters of this view were opposed to convertibility because it limited the government's freedom to act. They argued that the commitment to convertibility was nothing more than a needless restraint on the ability of the government to conduct what was euphemistically described as a "rational" monetary policy. By the end of the 1920 s, this view had won many adherents and the commitment to convertibility was abandoned soon afterwards by one country after another.

\footnotetext{
${ }^{15}$ For a good discussion of this episode, see Andreades (1909, chap. 4).

${ }^{16}$ For a discussion of this, see Hammond (1957).

${ }^{17} \mathrm{I}$ refer, of course, to the growing influence of Keynesian ideas.
} 


\section{Cato JOURNAL}

There was no longer any guarantee that the currency would retain its value. The value of the currency was henceforth to be determined by the amount of it issued by the government. The proponents of inconvertible currency were not particularly concerned because they believed that the extra leeway this gave the government would be used to promote the social good. Even if that meant a certain amount of inflation, they argued, that would still be in the public interest if it helped achicve a "higher" social good than price stability-such as lower unemployment. The price level had thus changed from something the private sector could depend upon in making plans for the future to become a policy tool for the government to manipulate as it pleased.

The argument for managed currencies was based on the premise that the governmont could be expected to promote the social good, provided only that it was given sufficient power. But this requires that the interests of the state coincide with those of the rest of society, and proponents of governments' economic intervention have failed completely to recognize a serious conflict of interest between the two. This conflict is particularly acute on the question of price stability. The private sector needs a stable framework in which to go about its business and make plans for the future. It therefore has a strong vested interest in the maintenance of price stability. The state has no such interest. Its interest, in fact, is usually to create inflation to reduce the real value of its debt to the private sector. For the state, inflation is simply a form of taxation, and a form of taxation that has the political advantage of being heavily disguised. Whatever damage it might do to the private sector, it enables the state to raise revenue without most of the electorate even realizing that they are being taxed. The new fiduciary monetary regime thus has an in-built inflationary bias, and the result has been the great inflations of the postwar years.

\section{Demands for Further State Intervention}

The kinds of intervention into the monetary system we have examined so far were motivated principally by governments' desire for more revenue. But each of these interventions destabilized the monetary system in its own way: the monopolization of the note issue prevented a clearing system's arising and thus made overissues of notes longer lasting and more damaging; the restrictions placed on deposit banks weakened them and made them vulnerable to shocks; and the state's persistent demands for revenue from the banking system weakened and eventually destroyed the guarantee of price 
stability provided by convertibility, and thereby paved the way for inflation.

These problems of monetary instability gave rise to a great deal of public debate, and there were countless proposals of measures to deal with them. Most of these proposals advocate further state intervention oblivious of the fact that state intervention is the cause of the problem in the first place. The state has thus intervened further to correct the instability it caused, and generally made it even worse.

One such intervention was the introduction of a legal requirement that banks of issue redeem their notes on demand, that is, the prohibition of option clauses. ${ }^{18}$ This measure was motivated by two beliefs, one true and the other false. It is true that convertibility is a guarantee that notes will retain their value, but it is not true that a failure to force redemption on demand would lead banks to issue notes of inferior value. As the earlier discussion of free banking pointed out, all that is needed to ensure that notes keep their value is a legal system to enforce convertibility contracts. Because of the greater stability of the issuing banks, both the public and the banks stand to gain when banks have the option to defer the redemption of their notes. Enforcing convertibility on demand deprived the banking system of the benefits of option clauses, and thereby exposed it to the danger of bank runs.

There are many other regulations imposed on the banking system that, while designed to make it more stable, have the opposite effect. Two others will suffice here. The first was the Bank Charter Act of 1844 that separated the Bank of England into an Issue Department, which issued notes against a 100 percent marginal reserve requirement, and a Banking Department, which took in deposits and carried on the rest of the Bank's business. The act was motivated by the currency school's belief that monetary crises were principally caused by the Bank's overexpanding its note issues. The aim of the legislation was to restore monetary stability by ensuring that the Bank was forced to maintain sufficient reserves to be able to redeem its notes at any time. Unfortunately, the act also prohibited the Issue Department from lending to the Banking Department, and this exposed the Bank to a serious danger. If depositors withdrew sufficient deposits, then the Banking Department that operated with fractional reserves could default. If this happened, the Bank itself would default despite the fact that it still had plenty of reserves in the Issue Department.

\footnotetext{
${ }^{18}$ Option clauses were prohibited in the United Kingdom by an Aet of 1765 . They appear never to have been allowed in the United States.
} 


\section{Cato journal.}

This nearly happened on three occasions, and the Bank was saved only by the governments' intervening to suspend the act and allow the Issue Department to lend gold to the Banking Department.

The other example was the institution of compulsory, governmentcontrolled deposit insurance in the United States after the bank failures of the early 1930s. This was introduced in the belief that the banking system would be more stable if banks were free of the danger of sudden runs for liquidity. Unfortunately, proponents of deposit insurance failed to take account of how the banking system would respond to the incentive structure implied by the deposit insurance regime. ${ }^{19}$ The new regime encouraged banks to take risks they would otherwise have avoided. The banks that took greater risks could offer stockholders higher expected returns, and the depositors were no longer particularly concerned about these risks because they were insured. At the same time, there was no attempt by the FDIC to charge risk-related premiums. As a result, the system had the effect of subsidizing risk taking. Over time the banks responded to these incentives and adopted policies that are more likely to lead to failure. Thus the FDIC regime had a stabilizing effect in the short-run, but a destabilizing one in the longer run.

\section{Conclusion}

This paper has argued that the free market would have provided a stable monetary system had it been left alone to do so. Its stability would have arisen from the attempts of private individuals to protect themselves against shocks. There is, as it were, no public good aspect of stability that requires the state to intervene to provide more of it than the free market would provide on its own. Indeed, state intervention often has just the opposite effect because it suppresses the automatic stabilizing mechanisms that would have evolved under laissez-faire.

This suggests that the free market would still be capable of providing a stable monetary system if the appropriate conditions were established. The problem is then to find the safest way to dismantle the apparatus of state intervention and establish those conditions. We must bear in mind that private agents have grown used to intervention and have adapted to it. Some of them are dependent on it (like some banks are dependent on the FDIC). We must also bear in

\footnotetext{
${ }^{19}$ Congress was apparently aware of the danger that deposit insurance might lead banks to take more risks, but it tried to tackle the problem by restricting what it considered to be excessively risky activities. $A$ strong case could be made that that only made matters worse.
} 
mind that people will not adapt to laissez-faire overnight, and the automatic stabilizing mechanisms it would provide will take time to evolve. Our task is therefore to design a program that will take us to laissez-faire but avoid destabilizing the monetary system before we get there. ${ }^{20}$

\section{References}

Andreades, A. History of the Bank of England. London: P. S. King, 1909.

Cambridge Economic History of Europe, vol. 5: The Economic Organization of Early Modern Europe. Cambridge: Cambridge University Press, 1977.

Dowd, Kevin. The State and the Monetary System. Vancouver: The Fraser Institute, forthcoming 1988.

Goodhart, C.A.E. The Evolution of Central Banks: A Natural Development? Suntory-Toyota Centre for Economics and Related Disciplines, London School of Economics, 1985.

Gorton, Gary. "Bank Suspension of Convertibility." Journal of Monetary Economics 15 (1985): 177.993.

Gorton, Gary. "Banking Panics and Business Cycles," Working Paper No. 86-9, Federal Reserve Bank of Philadelphia, March 1986.

Hammond, Bray. Banks and Politics in America: From the Revolution to the Civil War. Princeton: Princeton University Press, 1957.

Menger, Carl. "On the Origin of Money." Economic Journal (1892): 239-55.

Meulen, Henry. Free Banking: An Outline of a Policy of Individualism. London: Macmillan, 1934.

Rockoff, Hugh. "The Free Banking Era: A Reexamination." Journal of Money, Credit, and Banking 6 (May 1974): 141-67.

Rolnick, A. J., and Weber, Warren E. "New Evidence on the Free Banking Era." American Economic Review. 73 (December 1983): 1080-91.

Selgin, George A. The Theory of Free Banking. Totowa, N.J.: Rowman and Littlefield, forthcoming 1988.

Selgin, George A., and White, Lawrence H. "The Evolution of a Free Banking System." Economic Inquiry. 25 (July 1987): 439-57.

Smith, V. C. The Rationale of Central Banking. London: P. S. King, 1936.

Timberlake, Richard H., Jr. "The Central Banking Role of Clearinghouse Associations." Journal of Money, Credit, and Banking. 16 (February 1984): $1-15$.

Wesslau, O. E. Rational Banking Versus Banking Monopoly. London: Elliot Stock, 1887.

White, Lawrence H. Free Banking in Britain: Theory, Experience, and Debate, 1800-1845. Cambridge: Cambridge University Press, 1984.

${ }^{20}$ For further information about the theory of free banking, see Smith (1936), White (1984), Selgin (1988), and Dowd (1988). For more on its historical experiences, see White (1984) for Scotland, and Rockoff (1974) and Rolnick and Weber (1983) for the United States. 